FOLIA POMERANAE UNIVERSITATIS TECHNOLOGIAE STETINENSIS

Folia Pomer. Univ. Technol. Stetin., Oeconomica 2017, 335(87)2, 123-130

Robert KOWALAK

\title{
ANALIZA OPŁACALNOŚCI URUCHOMIENIA ANGLOJĘZYCZNYCH GRUP NA UNIWERSYTECIE EKONOMICZNYM WE WROCŁAWIU
}

\author{
THE ANALYSIS OF EFFECTIVENESS OF A NEW GROUPS IN ENGLISH \\ LANGUAGE ON THE EXAMPLE OF A MAJOR BUSINESS MANAGEMENT
}

Katedra Rachunku Kosztów, Rachunkowości Zarządczej i Controllingu, Uniwersytet Ekonomiczny we Wrocławiu, ul. Komandorska 118/120, 54-345 Wrocław, e-mail: robert.kowalak@ue.wroc.pl

\begin{abstract}
Summary. This article presents the analysis of effectiveness of starting new groups of major in English language for full-times students on Faculty of Management, Computer Science and Finance of Wrocław University of Economics. The main purpose is presentation a method of calculation additional costs without standard costs for students studied in Polish language, sales and profit. Added costs are wages for teachers have been teaching in English language. The calculation should be prepared for Dean of Faculty before starting new major, because he has to have acceptation of Rector.
\end{abstract}

Słowa kluczowe: analiza opłacalności, kierunek studiów, wyższa uczelnia.

Key words: analysis of effectiveness, major of study, university.

\section{WSTĘP}

Przed uczelniami wyższymi - zarówno publicznymi, jak i prywatnymi - są stawiane trudne zadania związane z konkurencyjnością na rynku, podobne jak w wypadku przedsiębiorstw prywatnych. Władze uczelni muszą sprostać oczekiwaniom rynku edukacyjnego oraz indywidualnym potrzebom studentów i oferować programy nauczania dostosowane do oczekiwań otoczenia. To student decyduje, gdzie chce studiować i to on podejmuje decyzję, którą uczelnię wybierze. Jednym z kryteriów takiego wyboru jest oferta programowa uczelni. Uczelnie starają się pozyskiwać studentów zagranicznych i oferować programy studiów przygotowane dla polskich studentów, którzy zamierzają pracować w międzynarodowych przedsiębiorstwach. W związku z tym nieodzowne jest posiadanie w ofercie nie tylko pojedynczych przedmiotów w języku angielskim, ale również całych anglojęzycznych cyklów kształcenia zarówno na studiach I, jak i II stopnia.

Celem artykułu jest przedstawienie analizy opłacalności prowadzenia zajęć w języku angielskim dla nowych grup studenckich na studiach stacjonarnych kierunków polskojęzycznych. Na potrzeby oceny opłacalności uruchomienia tych grup przyjęto, że przychody osiągnięte z opłat studentów za studiowanie w języku angielskim muszą pokryć dodatkowe koszty wynagrodzenia pracowników dydaktycznych (dodatek za prowadzenie zajęć w języku angielskim). Uruchomienie grup anglojęzycznych nie musi przynosić zysków, ale też nie może generować strat. Celem ich uruchomienia jest zwiększenie konkurencyjności uczelni na rynku edukacyjnym. 
Przedstawiona w artykule koncepcja bazuje na rozwiązaniu zaproponowanym przez autora dziekanowi Wydziału Zarządzania Informatyki i Finansów Uniwersytetu Ekonomicznego we Wrocławiu. W obliczeniach została uwzględniona specyfika działalności uczelni publicznej oraz akty prawne obowiązujące na badanej uczelni.

\section{MATERIA I METODY}

Przeprowadzone badania miały głównie charakter diagnostyczny (Apanowicz 2002). W trakcie obliczania opłacalności uruchomienia zajęć dla grup studiujących w języku angielskim, według programów dla kierunków polskojęzycznych, zwracano uwagę, aby uwzględnić wszystkie czynniki, które wpływają na podjęcie decyzji przez zarządzających wydziałem i uczelnią, eliminując czynniki nieistotne, charakterystyczne dla grup polskojęzycznych. Przed przeprowadzeniem badania postawiono hipotezę, że uruchomienie nawet jednej grupy studiującej w języku angielskim na kierunku polskojęzycznym jest opłacalne.

Do badań wykorzystano dostępne informacje związane z funkcjonowaniem wydziału i uczelni. Podstawowym materiałem były uchwały, rozporządzenia, zarządzenia obowiązujące na Uniwersytecie Ekonomicznym we Wrocławiu. Dodatkowo posiłkowano się aktami prawnymi obowiązującymi na uczelniach wyższych w Polsce.

\section{WARUNKI URUCHOMIENIA KIERUNKU STUDIÓW W JĘZYKU ANGIELSKIM}

Konkurencyjność szkół wyższych wymaga analizy opłacalności uruchomienia każdego nowego kierunku studiów. Uczelnie prywatne poszerzają bardzo szybko swoją ofertę i stają się konkurencyjne dla uczelni publicznych. Specyfika uczelni publicznej, bazującej na dotacjach z budżetu państwa, ogranicza pole manewru w zakresie uruchamiania nowych kierunków dla studentów studiów stacjonarnych. Uczelnie publiczne na studiach stacjonarnych mogą mieć określoną liczbę grup, co oznacza, że kierując się limitem ustalonym przez Ministra Nauki i Szkolnictwa Wyższego, należy przesunąć co najmniej jedną grupę na nowy kierunek, aby go uruchomić. To, czy nowy kierunek będzie opłacalny już dla jednej grupy, zależy od bardzo wielu czynników, podobnie jak uruchomienie wersji anglojęzycznej dla grup kierunku prowadzonego w języku polskim. Jednakże w tym wypadku analiza opłacalności nie musi być tak samo kompleksowa, gdyż zakłada się, że kierunek polskojęzyczny jest opłacalny, tzn. dotacje pokrywają koszty bezpośrednie i pośrednie kierunku.

Uruchomienie nowego kierunku na uczelni reguluje Rozporządzenie Ministra Nauki i Szkolnictwa Wyższego z dnia 3 października 2014 roku w sprawie warunku prowadzenia studiów na określonym kierunku i poziomie kształcenia. Rozporządzenie to w paragrafie 1 określa m.in.:

- warunki, jakie musi spełniać program kształcenia, oraz opis kwalifikacji na studiach pierwszego i drugiego stopnia;

- warunki, jakie muszą spełniać jednostki organizacyjne uczelni, aby prowadzić studia na określonym kierunku, poziomie i o określonym profilu kształcenia, w tym: liczbę i kwalifikacje nauczycieli akademickich zaliczanych do minimum kadrowego, proporcje liczby nauczycieli akademickich zaliczonych do minimum kadrowego do liczby studentów na danym kierunku studiów; 
- kierunki studiów prowadzone jako jednolite studia magisterskie albo studia drugiego stopnia oraz kierunki studiów, które mogą być prowadzone jako jednolite studia magisterskie. Uruchomienie kierunku w języku angielskim, podobnie jak w języku polskim, wymaga przedstawienia w programie studiów informacji dotyczących:

- formy studiów;

- liczby semestrów i liczby punktów ECTS niezbędnych do uzyskania kwalifikacji odpowiadających poziomowi kształcenia;

- modułów zajęć - lub grupy zajęć - wraz z przypisaniem do każdego modułu efektów kształcenia oraz liczby punktów ECTS;

- sposobów weryfikacji zakładanych efektów kształcenia osiąganych przez studenta;

- planu studiów;

- łącznej liczby punktów ECTS, którą student musi uzyskać w ramach zajęć, wymagających bezpośredniego udziału nauczycieli akademickich i studentów, z zakresu nauk podstawowych właściwych dla danego kierunku studiów, do których odnoszą się efekty kształcenia dla tego kierunku, poziomu i profilu kształcenia oraz o charakterze praktycznym, w tym zajęć laboratoryjnych, warsztatowych i projektowych;

- minimalnej liczby punktów ECTS, którą student musi uzyskać w ramach niezwiązanych z kierunkiem studiów zajęć ogólnouczelnianych lub zajęć na innym kierunku studiów;

- liczby punktów ECTS, którą student musi uzyskać w ramach zajęć z obszarów nauk humanistycznych i nauk społecznych, nie mniejszej niż 5 punktów ECTS;

- liczby punktów ECTS, którą student musi uzyskać w ramach zajęć z języka obcego;

- liczby punktów ECTS, którą student musi uzyskać w ramach zajęć z wychowania fizycznego;

- wymiaru, zasad i formy odbywania praktyk zawodowych dla kierunku studiów o profilu praktycznym, a w przypadku kierunku studiów o profilu ogólnoakademickim - jeżeli program kształcenia na tych studiach przewiduje praktyki;

- łącznej liczby punktów ECTS, którą student musi uzyskać w ramach praktyk zawodowych na kierunku studiów o profilu praktycznym, a w przypadku kierunku studiów o profilu ogólnoakademickim - jeżeli program kształcenia na tych studiach przewiduje praktyki.

Zgodnie ze wspomnianym rozporządzeniem, jeśli kierunek jest już uruchomiony w języku polskim, władze wydziału oraz władze uczelni nie muszą przygotowywać nowej dokumentacji związanej z uruchomieniem grup, których zajęcia są prowadzone w języku angielskim; zgodnie z prawem jest to ten sam kierunek. Oznacza to, że w całości program studiów, liczba godzin zajęć, liczba punktów ECTS dla studentów studiujących w języku angielskim muszą być identyczne jak dla studentów studiujących w języku polskim. Wystarczy więc, że Rada Wydziału w formie uchwały podejmie decyzję związaną z uruchomieniem anglojęzycznych grup dla kierunku polskojęzycznego; schemat procedury przedstawia ryc. 1 . Jak pokazuje ryc. 1, ścieżki są różne i związane z różnymi wymogami administracyjnymi. 


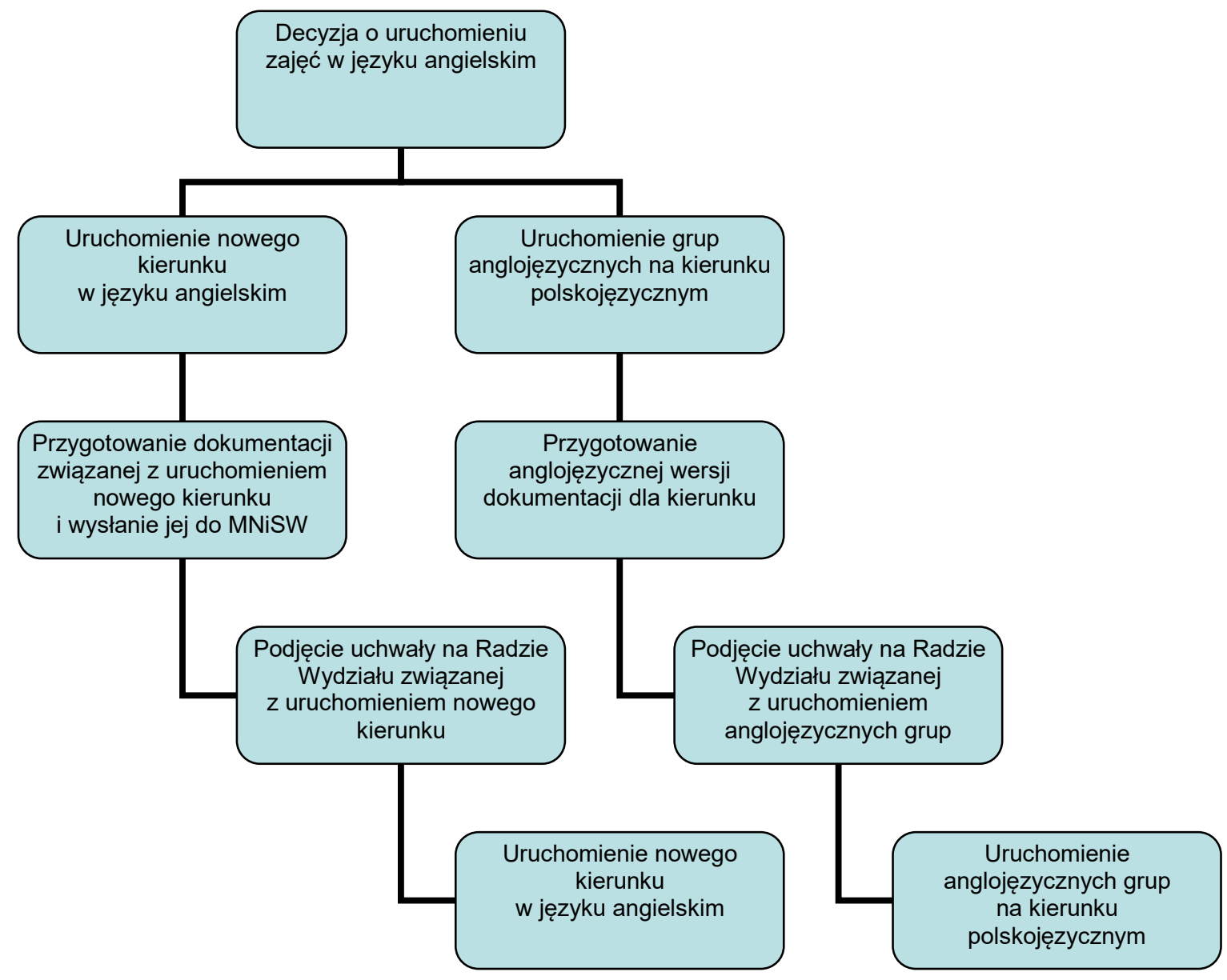

Ryc. 1. Procedura uruchomienia zajęć w języku angielskim

\section{ANALIZA OPŁACALNOŚCI GRUP ANGLOJĘZYCZNYCH BUSINESS MANAGEMENT}

Analiza opłacalności uruchomienia grup studiujących w języku angielskim dla studentów studiów stacjonarnych polega na zestawieniu planowanych przychodów z tytułu opłat wniesionych przez studentów za studiowanie w języku angielskim z kosztami uruchomienia dodatkowej grupy (lub grup). Analiza ta uwzględnia fakt, że grupa na kierunku w języku angielskim będzie zastępować grupę, w której studiowali studenci w języku polskim. Oznacza to, że jeśli np. zaplanowano 5 grup dla kierunku zarządzanie, to uruchomienie grup oznaczonych jako Business Management spowoduje zmniejszenie rekrutacji studentów na kierunek zarządzanie o co najmniej jedną grupę. W związku z tym analiza opłacalności dotyczy wyniku finansowego osiąganego w rezultacie dodatkowych przychodów i dodatkowych kosztów.

Przychody są ustalane na podstawie planowanej liczby studentów i opłat, jakie muszą oni wnieść za zajęcia w języku angielskim.

Koszty są związane z uruchomieniem dodatkowej grupy studiującej w języku angielskim oraz z dodatkowymi kosztami związanymi z prowadzeniem zajęć w języku angielskim. 
Opłacalność uruchomienia grupy w języku angielskim oblicza się jako różnicę między osiąganymi przychodami a kosztami. W przypadku, gdy przychody są co najmniej równe kosztom, można rozważać uruchomienie wersji anglojęzycznej polskojęzycznego kierunku.

Mierzona w ten sposób opłacalność zależy od wielu czynników, które się różnią w zależności od uczelni. Każda uczelnia może wyznaczyć minimalne kryteria związane z uruchomieniem anglojęzycznej wersji kierunku prowadzonego w języku polskim. Podstawową determinantą jest minimalna liczba studentów w grupie, o czym decydują władze uczelni. Następną determinantą są opłaty studentów za zajęcia w języku angielskim i stawki dopłat do wynagrodzeń pracowników za prowadzenie zajęć w języku angielskim.

W roku akademickim 2016/2017 na Wydziale Zarządzania Informatyki i Finansów Uniwersytetu Ekonomicznego we Wrocławiu władze postanowiły rozszerzyć ofertę dla studentów pragnących studiować w języku angielskim na kierunkach uruchomionych w języku polskim. Są to zarządzanie (Business Management), logistyka (Logistics). Obecnie na wydziale są prowadzone zajęcia w języku angielskim na kierunkach finanse i rachunkowość (Bachelor Studies in Finance oraz Master Studies in Finance) oraz informatyka w biznesie (Business Informatics).

Analiza opłacalności obejmuje 3 części: obliczenie liczby etatów osób zatrudnionych przy prowadzeniu zajęć na nowym kierunku, obliczenie kosztów wykładów, obliczenie planowanych przychodów z opłat wniesionych przez studentów za studiowanie w języku angielskim, zestawienie przychodów i kosztów. Analiza opłacalności obejmuje uruchomienie kierunku z minimalną liczbą grup studiujących w języku angielskim, czyli z jedną grupą. Jeśli okaże się, że uruchomienie anglojęzycznej wersji zajęć będzie opłacalne dla jednej grupy, to zwiększenie liczby grup będzie również opłacalne.

Dodatkowe koszty obejmują wynagrodzenie pracowników dydaktycznych wraz z narzutami, które są związane z prowadzeniem zajęć w języku angielskim; obejmuje jedynie dodatek do wynagrodzenia, który musi sfinansować samodzielnie uczelnia. Dodatek ten jest uregulowany uchwałą senatu Uniwersytetu Ekonomicznego we Wrocławiu.

Podstawową kwestią jest oszacowanie średniej liczby etatów do rozliczenia w całym okresie studiowania. Podstawowe założenia dla kierunku Business Management na studiach pierwszego stopnia są następujące:

- liczba semestrów - 6,

- liczba godzin na 6 semestrach - 1955.

Szczegółowe obliczenia związane z ustaleniem średniej liczby etatów prezentuje tab. 1.

Jak wynika z tab. 1, średnia liczba etatów wynosi 2,27 , co oznacza, że do obsługi kierunku dodatkowo potrzebne są 2 etaty. Jest to obliczenie szacunkowe w celu określenia kosztów wynagrodzenia. Największa liczba etatów wynosi 3,79. Jest to sytuacja, która generuje najwyższe koszty dla uczelni. Występuje wówczas, gdy dla pracowników stosuje się najwyższy mnożnik (przelicznik), wynoszący 1,2 za zajęcia anglojęzyczne. Pracownik musiałby wszystkie swoje zajęcia w semestrze prowadzić w języku angielskim ${ }^{1}$. Średni dodatek za zajęcia został obliczony na podstawie dotychczas prowadzonych zajęć w języku angielskim na innych kierunkach².

\footnotetext{
${ }^{1}$ Do tej pory na wydziale nie wystąpił taki przypadek.

2 Obliczenia przeprowadzono na podstawie danych z roku akademickiego 2014/2015 oraz z roku akademickiego $2015 / 2016$.
} 
Tabela 1. Szacowanie średniej liczby etatów

\begin{tabular}{|l|c|}
\hline \multicolumn{1}{|c|}{ Wyszczególnienie } & Liczba etatów \\
\hline Liczba godzin ogółem & 1955,00 \\
\hline Języki obce [godz.] & 30,00 \\
\hline Wychowanie fizyczne [godz.] & 210,00 \\
\hline BHP [godz.] & 4,00 \\
\hline IEŹIN [godz.] & 6,00 \\
\hline Liczba godzin ogółem płatnych & 1705,00 \\
\hline Średnia liczba godzin płatnych w semestrze & 284,00 \\
\hline Średnia liczba miesięcy w semestrze & 4,00 \\
\hline Maksymalny dodatek za angielski & 0,30 \\
\hline Średni dodatek za angielski & 0,18 \\
\hline Mnożnik wynagrodzenia maksymalny & 1,20 \\
\hline Mnożnik wynagrodzenia średni & 0,72 \\
\hline Liczba etatów w semestrze & 3,16 \\
\hline Liczba etatów do rozliczenia maksymalna & 3,79 \\
\hline Liczba etatów do rozliczenia średnia & 2,27 \\
\hline
\end{tabular}

Ponadto na kierunku prowadzonym w języku angielskim należy uruchomić wykłady. Obliczenie kosztów dodatkowych wykładów jest uzależnione od stawki dla pracownika; obliczenia te zaprezentowano $w$ tab. 2. Należy w tym miejscu zwrócić uwagę, że przedstawione w niej koszty nie uwzględniają przelicznika dla zajęć prowadzonych w języku angielskim.

Tabela 2. Koszt wykładów

\begin{tabular}{|l|c|}
\hline \multicolumn{1}{|c|}{ Wyszczególnienie } & Wartość \\
\hline Liczba godzin wykładowych ogółem & 767 \\
\hline Średnia liczba godzin wykładowych w semestrze & 128 \\
\hline Stawka za godzinę dla profesora [zł/godz.] & 90 \\
\hline Stawka za godzinę dla doktora habilitowanego [zł/godz.] & 70 \\
\hline Stawka za godzinę dla doktora [zł/godz.] & 60 \\
\hline Koszt wykładów profesora w semestrze [zł] & 13881 \\
\hline Koszt wykładów doktora habilitowanego w semestrze [zł] & 8951 \\
\hline Koszt wykładów doktora [zł] & 7673 \\
\hline
\end{tabular}

Stawki za godzinę dla pracowników naukowo-dydaktycznych są ustalane przez Rektora. Przedstawione w tab. 2 stawki zostały określone w Zarządzeniu nr 20/2015 Rektora Uniwersytetu Ekonomicznego we Wrocławiu z dnia 29 kwietnia 2015 roku w sprawie stawek wynagrodzenia za pracę w godzinach ponadwymiarowych na studiach stacjonarnych i niestacjonarnych pierwszego, drugiego i trzeciego stopnia oraz stawek wynagrodzenia za prowadzenie zajęć dydaktycznych przez osoby niezatrudnione na Uczelni na studiach stacjonarnych i niestacjonarnych pierwszego, drugiego i trzeciego stopnia. Przychody, będące jednocześnie wpływami, bazują na opłatach wnoszonych przez studentów. Opłaty te są naliczane zgodnie z Zarządzeniem nr 29/2014 Rektora Uniwersytetu Ekonomicznego we Wrocławiu z dnia 4 kwietnia 2014 roku w sprawie opłat za studia wnoszonych przez cudzoziemców i obywateli polskich podejmujących kształcenie na Uniwersytecie Ekonomicznym we Wrocławiu w roku akademickim 2014/2015. Szacowane przychody z opłat studentów dla studiów w całości i dla semestru są przedstawione $w$ tab. 3 . 
Tabela 3. Szacowane przychody z opłat studentów

\begin{tabular}{|l|c|}
\hline \multicolumn{1}{|c|}{ Wyszczególnienie } & Wartość [zł] \\
\hline Liczba studentów w grupie & 24 \\
\hline Opłata za semestr & 1000 \\
\hline Przychody za semestr & 24000 \\
\hline Przychody za cały okres studiów & 144000 \\
\hline
\end{tabular}

Jak wynika z danych przedstawionych $w$ tab. 3, przyjęto, że grupa (liczba zrekrutowanych) studentów obejmuje 24 osoby $^{3}$. Jest to minimalna liczba studentów, dla której prorektor ds. dydaktyki wyraża zgodę na uruchomienie grupy. Maksymalna liczba osób w grupie wynosi $36 \mathrm{w}$ pierwszym semestrze oraz $32 \mathrm{w}$ pozostałych semestrach. Jeśli uruchomienie grupy anglojęzycznej będzie opłacalne dla 24 osób, to będzie też opłacalne dla każdej większej liczby osób. Ponadto zakłada się, że wszyscy studenci ukończą studia z pozytywnym wynikiem. Przy liczbie osób w grupie większej niż 24 można przyjąć, że część z nich nie ukończy studiów.

Obliczenie opłacalności dla anglojęzycznej grupy na kierunku zarządzanie (określanej jako Business Management) zostało zaprezentowane w tab. 4.

Tabela 4. Wynik finansowy dla kierunku zarządzanie (Business Management)

\begin{tabular}{|l|r|}
\hline \multicolumn{1}{|c|}{ Wyszczególnienie } & Wartość [zł] \\
\hline Przychody za semestr & 24000 \\
\hline Przychody za cały okres studiów & 144000 \\
\hline Średnie koszty za semestr & 21995 \\
\hline Średnie koszty za cały okres studiów & 131967 \\
\hline Wynik finansowy za semestr & 2005 \\
\hline Wynik finansowy za studia & 12033 \\
\hline
\end{tabular}

Jak wynika z obliczeń przedstawionych w tab. 4, uruchomienie anglojęzycznej grupy dla polskojęzycznego kierunku jest opłacalne. Jeśli jest opłacalne dla jednej grupy, to będzie również opłacalne dla większej liczby grup (nie rosną wtedy koszty związane z prowadzeniem wykładów w języku angielskim).

$\mathrm{Na}$ koniec warto wspomnieć, że na podobnych zasadach szacowano opłacalność uruchamiania kierunku Logistics (anglojęzycznej wersji kierunku logistyka).

\section{PODSUMOWANIE}

Jak wynika z przeprowadzonych rozważań, na potrzeby oceny opłacalności uruchomienia nowych grup anglojęzycznych na kierunku prowadzonym w języku polskim na studiach stacjonarnych I stopnia na uczelni publicznej nie jest konieczne przeprowadzanie szczegółowej kalkulacji kosztów. Jeśli uczelnia nie płaciłaby pracownikom dodatkowo za prowadzenie zajęć w języku angielskim, a studenci nie opłacaliby zajęć w języku angielskim, to ocena byłaby taka sama jak ocena zajęć prowadzonych w języku polskim.

\footnotetext{
${ }^{3}$ Liczebność studentów w grupach reguluje Uchwała nr R.0000.38.2016 Senatu Uniwersytetu Ekonomicznego we Wrocławiu z dnia 28 kwietnia 2016 roku w sprawie zasad planowania i rozliczania zajęć dydaktycznych w roku akademickim 2016/2017 (par.7). W uzasadnionych przypadkach Rektor może zmniejszyć liczbę studentów w grupie do 20 osób.
} 
Uzyskane wyniki oceny opłacalności uruchomienia anglojęzycznej wersji kierunku zarządzanie (Business Management) na Wydziale Zarządzania Informatyki i Finansów Uniwersytetu Ekonomicznego we Wrocławiu dostarczają interesujących spostrzeżeń:

1. Opłacalność prowadzenia zajęć w języku angielskim jest uzależniona od liczby zrekrutowanych studentów.

2. Stawka wynagrodzenia pracownika ma bardzo istotny wpływ na opłacalność uruchomienia kierunku.

Wyniki przedstawionych obliczeń wskazują, że można sterować opłacalnością uruchomienia grup studenckich w języku angielskim, decydując się na utrzymanie odpowiedniej proporcji między liczbą studentów a dodatkami do wynagrodzeń pracowników prowadzących zajęcia w języku angielskim. W analizie przedstawionej w artykule nie podejmowano szczegółowych symulacji dla różnych sytuacji (takich jak: zmniejszająca się liczba studentów w całym cyklu studiów, różnych skład kadry prowadzącej zajęcia w języku angielskim, zmiany w rozkładzie zajęć między wykładami a ćwiczeniami). Wstępna obsada zajęć jest przygotowywana dopiero przed rozpoczęciem semestru (we wrześniu przed rozpoczęciem semestru zimowego, w lutym przed rozpoczęciem semestru letniego). Skrajnie pesymistyczny przypadek, że wszystkie zajęcia będą prowadzone przez profesorów zwyczajnych, nie był rozpatrywany, gdyż prawdopodobieństwo jego wystąpienia jest niewielkie (w praktyce zerowe).

Analogicznie można przeprowadzić rozważania dotyczących studiów drugiego stopnia. $\mathrm{Na}$ analizowanym wydziale przyjmuje się, że uruchomienie studiów I stopnia automatycznie wymaga przedstawienia oferty dla studiów II stopnia, gdyż student musi mieć możliwość kontynuowania studiów na tym samym kierunku i w tym samym języku.

\section{PIŚMIENNICTWO}

Apanowicz J. 2002. Metodologia ogólna. Gdynia, Bernardinum.

Rozporządzenie Ministra Nauki i Szkolnictwa Wyższego z dnia 3 października 2014 roku w sprawie warunku prowadzenia studiów na określonym kierunku i poziomie kształcenia. DzU z 9.10.2014 r., poz. 1370.

Uchwała nr R.0000.36.2015 Senatu Uniwersytetu Ekonomicznego we Wrocławiu z dnia 28 maja 2015 r. w sprawie zasad planowania i rozliczania zajęć dydaktycznych w roku akademickim 2015/2016, http://www.ue.wroc.pl, dostęp: październik 2016.

Uchwała nr R.0000.38.2016 Senatu Uniwersytetu Ekonomicznego we Wrocławiu z dnia 28 kwietnia 2016 r. w sprawie zasad planowania i rozliczania zajęć dydaktycznych w roku akademickim 2016/2017, http://www.ue.wroc.pl, dostęp: październik 2016.

Zarządzenie nr 29/2014 Rektora Uniwersytetu Ekonomicznego we Wrocławiu z dnia 4 kwietnia 2014 roku w sprawie opłat za studia wnoszonych przez cudzoziemców i obywateli polskich podejmujących kształcenie na Uniwersytecie Ekonomicznym we Wrocławiu w roku akademickim 2014/2015, http://www.ue.wroc.pl, dostęp: październik 2016.

Zarządzenie nr 20/2015 Rektora Uniwersytetu Ekonomicznego we Wrocławiu z dnia 29 kwietnia 2015 roku w sprawie stawek wynagrodzenia za prace w godzinach ponadwymiarowych na studiach stacjonarnych i niestacjonarnych pierwszego, drugiego i trzeciego stopnia oraz stawek wynagrodzenia za prowadzenie zajęć dydaktycznych przez osoby niezatrudnione na Uczelni na studiach stacjonarnych i niestacjonarnych pierwszego, drugiego i trzeciego stopnia, http://www.ue.wroc.pl, dostęp: październik 2016. 